\title{
Inactivation of the novel avian influenza A (H7N9) virus under physical conditions or chemical agents treatment
}

Shumei Zou ${ }^{1,2}$, Junfeng Guo ${ }^{1,2}$, Rongbao Gao ${ }^{1,2}$, Libo Dong ${ }^{1,2}$, Jianfang Zhou ${ }^{1,2}$, Ye Zhang ${ }^{1,2}$, Jie Dong ${ }^{1,2}$, Hong Bo ${ }^{1,2}$, Kun Qin ${ }^{1,2}$ and Yuelong Shu ${ }^{1,2,3^{*}}$

\begin{abstract}
Background: In the spring of 2013, a novel avian-origin influenza A (H7N9) virus in Eastern China emerged causing human infections. Concerns that a new influenza pandemic could occur were raised. The potential effect of chemical agents and physical conditions on inactivation of the novel avian influenza H7N9 virus had not been assessed.

Methods: To determine the inactivation effectiveness of the novel avian influenza A (H7N9) virus under various physical conditions and chemical treatments, two H7N9 viruses A/Anhui/1/2013 and A/Shanghai/1/2013 were treated by varied temperatures, ultraviolet light, varied $\mathrm{pHs}$ and different disinfectants. The viruses with $10^{7.7} \mathrm{EID}_{50}$ were exposed to physical conditions (temperature, ultraviolet light and $\mathrm{pH}$ ) or treated with commercial chemical agents (Sodium Hypochlorite, Virkon ${ }^{\circledR}$-S, and Ethanol) respectively. After these treatments, the viruses were inoculated in SPF embryonated chicken eggs, the allantoic fluid was collected after $72-96$ hours culture at $35^{\circ} \mathrm{C}$ and tested by haemagglutination assay.

Results: Both of the tested viruses could tolerate conditions under $56^{\circ} \mathrm{C}$ for 15 minutes or $60^{\circ} \mathrm{C}$ for 5 minutes, but their infectivity was completely lost under $56^{\circ} \mathrm{C}$ for 30 minutes, $65^{\circ} \mathrm{C}$ for 10 minutes, $70^{\circ} \mathrm{C}, 75^{\circ} \mathrm{C}$ and $100^{\circ} \mathrm{C}$ for 1 minute. It was also observed that the H7N9 viruses lost their infectivity totally after exposure of ultraviolet light irradiation for 30 minutes or longer time. Additionally, the viruses were completely inactivated at pH less than 2 for 0.5 hour or $\mathrm{pH} 3$ for 24 hours, however, viruses remained infectious under $\mathrm{pH}$ treatment of 4-12 for 24 hours. The viruses were totally disinfected when treated with Sodium Hypochlorite, Virkon ${ }^{\circledR}-S$ and Ethanol at recommended concentrations after only 5 minutes.

Conclusions: The novel avian influenza A (H7N9) virus can be inactivated under some physical conditions or with chemical treatments, but they present high tolerance to moderately acidic or higher alkali conditions. The results provided the essential information for public health intervention of novel H7N9 avian influenza outbreak.
\end{abstract}

Keywords: H7N9 virus, Inactivation, Temperatures, Ultraviolet light, pH, Disinfectants

\footnotetext{
* Correspondence: yshu@cnic.org.cn

${ }^{1}$ Chinese National Influenza Center, National Institute for Viral Disease Control and Prevention, 155 Changbai Road, Beijing 102206, P.R China

${ }^{2}$ Key Laboratory for Medical Virology, National Health and Family Planning Commission, 155 Changbai Road, Beijing 102206, P.R China

Full list of author information is available at the end of the article
} 


\section{Background}

On March 31, 2013, a novel reassortant avian influenza A (H7N9) virus (AIV A (H7N9)) with genomic features of low pathogenic virus causing severe infections in humans was identified in China [1]. As of Aug 20, 2013, a total of 134 human cases with avian influenza H7N9 virus infection were reported from 10 provinces and 2 municipalities in mainland China, and among them 45 died [2]. In order to minimise the animal and human health impacts, it is of crucial importance that avian influenza virus (AIV) infections in poultry are controlled. Understanding the potential effect of chemical and physical treatments on inactivation of the novel avian influenza A (H7N9) virus is significant to the implementation of proper public intervention measures. This study was designed to evaluate the effectiveness of various physical conditions (temperature, ultraviolet light (UV) and pHs), and chemical agents (Sodium Hypochlorite, Virkon ${ }^{\circledR}-\mathrm{S}$, and Ethanol) against avian influenza H7N9 viruses. The results of this study would provide evidences for proper virus inactivation methods and development of public hygiene measures.

\section{Results}

\section{Inactivation efficacy under different heat treatments}

To evaluate the effectiveness of heat treatments in inactivating the novel avian influenza H7N9 virus, $50 \mu \mathrm{l}$ virus stock solutions containing $10^{7.7}$ egg infectious dose $\left(10^{7.7} \mathrm{EID}_{50} / 50 \mu \mathrm{l}\right)$ viruses were treated at $56^{\circ} \mathrm{C}, 65^{\circ} \mathrm{C}$, $70^{\circ} \mathrm{C}, 75^{\circ} \mathrm{C}$ and $100^{\circ} \mathrm{C}$. As shown in Table 1 , one out of six eggs of A/Anhui/1/2013(H7N9) (AH1) and three out of six of A/Shanghai/1/2013(H7N9) (SH1) showed haemagglutination (HA) positive under the treatment of $56^{\circ} \mathrm{C}$ for $15 \mathrm{~min}$, both viruses from all six eggs survived under the treatment of $60^{\circ} \mathrm{C}$ for $5 \mathrm{~min}$, indicating the viruses could tolerate these conditions. While the $\mathrm{H} 7 \mathrm{~N} 9$ viruses were completely inactivated to undetectable levels after $56^{\circ} \mathrm{C}$ for $30 \mathrm{~min}, 65^{\circ} \mathrm{C}$ for $10 \mathrm{~min}, 70^{\circ} \mathrm{C}, 75^{\circ} \mathrm{C}$ and $100^{\circ} \mathrm{C}$ for $1 \mathrm{~min}$.

\section{Inactivation efficacy under UV irradiation exposure}

To determine the efficacy of UV irradiation treatment in inactivating avian influenza H7N9 virus contaminated surface, $10^{7.7}$ EID $_{50}$ viruses were spread on a Petri dish and then treated with UV irradiation in a Biosafety Cabinet for varied times at room temperature. The results showed that the viruses were inactivated after exposed to UV irradiation for $30 \mathrm{~min}$ or longer (Table 2). It should be noted that under UV exposure for $20 \mathrm{~min}$, four out of six eggs were HA-positive with $\mathrm{AH} 1$ and one out of six were HA-positive with SH1. Moreover, both viruses were completely tolerant under exposure to UV for $10 \mathrm{~min}$.

\section{Inactivation efficacy of different $\mathrm{pH}$ conditions}

The inactivation efficacy of the avian influenza H7N9 viruses under different $\mathrm{pH}$ conditions with different time intervals was shown in Table 3. The two H7N9 viruses were inactivated from an initial dose of $10^{7.7} \mathrm{EID}_{50}$ to undetectable levels when exposed to $\mathrm{pH} 1-2$ for $30 \mathrm{~min}$ or $\mathrm{pH} 3$ overnight. However, the viruses still retained their infectivity when treated under $\mathrm{pH}$ 4-12 for $24 \mathrm{~h}$ or $\mathrm{pH} 3$ for $30 \mathrm{~min}$ or $1 \mathrm{~h}$. The results suggested that the novel avian influenza H7N9 virus has a strong tolerance to moderately acidic to higher alkali conditions.

\section{The efficacy of different disinfectants}

To investigate the resistance of the novel H7N9 viruses against various disinfectants, $50 \mu \mathrm{l}$ virus stock solutions containing $10^{7.7} \mathrm{EID}_{50}$ viruses were treated with 0.5 and $1 \%$ Sodium Hypochlorite, 0.5 and $1 \%$ Virkon $^{\circledR}-\mathrm{S}$, and $75 \%$ ethanol at room temperature respectively. As shown in Table 4, these two viruses were inactivated from an initial dose of $10^{7.7} \mathrm{EID}_{50}$ to undetectable levels after only 5 min when exposed to recommended concentrations of $0.5 \%$ or $1 \%$ sodium hypochlorite, $0.5 \%$ or $1 \%$ Virkon-S and $75 \%$ ethanol.

\section{Discussion}

The aim of this study was to identify commonly available inactivation methods or disinfection agents that might be used for public protection against the novel avian influenza A (H7N9) virus or the decontamination methods at laboratory or field conditions. The results indicated that the novel avian influenza H7N9 viruses can be effectively inactivated by temperature treatment under $56^{\circ} \mathrm{C}$ for

Table 1 Inactivation efficacy under heat treatments of the novel avian influenza A (H7N9) virus

\begin{tabular}{|c|c|c|c|c|c|c|c|c|c|c|c|c|c|c|c|c|}
\hline \multirow[t]{3}{*}{ Temperature } & \multicolumn{16}{|c|}{ Treatment time (minutes) } \\
\hline & \multicolumn{2}{|c|}{1} & \multicolumn{2}{|c|}{2} & \multicolumn{2}{|c|}{5} & \multicolumn{2}{|c|}{10} & \multicolumn{2}{|c|}{15} & \multicolumn{2}{|c|}{30} & \multicolumn{2}{|c|}{45} & \multicolumn{2}{|c|}{60} \\
\hline & $\mathrm{AH} 1$ & $\mathrm{SH} 1$ & $\mathrm{AH} 1$ & $\mathrm{SH} 1$ & $\mathrm{AH} 1$ & $\mathrm{SH} 1$ & $\mathrm{AH} 1$ & $\mathrm{SH} 1$ & $\mathrm{AH} 1$ & $\mathrm{SH} 1$ & $\mathrm{AH} 1$ & $\mathrm{SH1}$ & $\mathrm{AH} 1$ & $\mathrm{SH} 1$ & $\mathrm{AH} 1$ & $\mathrm{SH} 1$ \\
\hline $56^{\circ} \mathrm{C}$ & $\mathrm{NT}^{*}$ & NT & NT & NT & 6/6\# & $6 / 6$ & $6 / 6$ & $5 / 6$ & $1 / 6$ & $3 / 6$ & $0 / 6$ & $0 / 6$ & $0 / 6$ & $0 / 6$ & $0 / 6$ & $0 / 6$ \\
\hline $65^{\circ} \mathrm{C}$ & NT & NT & NT & NT & $6 / 6$ & $6 / 6$ & $0 / 6$ & $0 / 6$ & $0 / 6$ & $0 / 6$ & $0 / 6$ & $0 / 6$ & $0 / 6$ & $0 / 6$ & $0 / 6$ & $0 / 6$ \\
\hline $70^{\circ} \mathrm{C}$ & $0 / 6$ & $0 / 6$ & $0 / 6$ & $0 / 6$ & $0 / 6$ & $0 / 6$ & $0 / 6$ & $0 / 6$ & $0 / 6$ & $0 / 6$ & 0/6 & $0 / 6$ & $0 / 6$ & $0 / 6$ & $0 / 6$ & $0 / 6$ \\
\hline $75^{\circ} \mathrm{C}$ & $0 / 6$ & $0 / 6$ & $0 / 6$ & $0 / 6$ & $0 / 6$ & $0 / 6$ & $0 / 6$ & $0 / 6$ & $0 / 6$ & $0 / 6$ & $0 / 6$ & $0 / 6$ & $0 / 6$ & 0/6 & $0 / 6$ & $0 / 6$ \\
\hline $100^{\circ} \mathrm{C}$ & $0 / 6$ & $0 / 6$ & $0 / 6$ & $0 / 6$ & NT & NT & NT & NT & NT & NT & NT & NT & NT & NT & NT & NT \\
\hline
\end{tabular}

Note: *NT=No test. \#Infectivity to embryonated chicken eggs = (infected embryos)/(total embryos inoculated; $n=6)$ per treatment. 
Table 2 Inactivation efficacy under UV irradiation treatment of the novel avian influenza A (H7N9) virus

\begin{tabular}{|c|c|c|c|c|c|c|c|c|c|c|}
\hline \multirow[t]{3}{*}{ UV } & \multicolumn{10}{|c|}{ Exposure time (minutes) } \\
\hline & \multicolumn{2}{|c|}{10} & \multicolumn{2}{|c|}{20} & \multicolumn{2}{|c|}{30} & \multicolumn{2}{|c|}{45} & \multicolumn{2}{|c|}{60} \\
\hline & $\mathrm{AH} 1$ & $\overline{\mathrm{SH} 1}$ & $\overline{\mathrm{AH} 1}$ & $\overline{\mathrm{SH} 1}$ & $\mathrm{AH} 1$ & $\mathrm{SH} 1$ & $\overline{\mathrm{AH} 1}$ & $\overline{\mathrm{SH} 1}$ & $\overline{\mathrm{AH} 1}$ & SH1 \\
\hline & $6 / 6^{*}$ & $6 / 6$ & $4 / 6$ & $1 / 6$ & $0 / 6$ & $0 / 6$ & $0 / 6$ & $0 / 6$ & $0 / 6$ & $0 / 6$ \\
\hline
\end{tabular}

Note: *Infectivity to embryonated chicken eggs = (infected embryos)/(total embryos inoculated; $\mathrm{n}=6$ ) per treatment.

$30 \mathrm{~min}, 65^{\circ} \mathrm{C}$ for $10 \mathrm{~min}, 70^{\circ} \mathrm{C}, 75^{\circ} \mathrm{C}$ and $100^{\circ} \mathrm{C}$ for $1 \mathrm{~min}$. But, it should be noted that the $\mathrm{H} 7 \mathrm{~N} 9$ viruses still could survive after treatment under $56^{\circ} \mathrm{C}$ for 15 min or $65^{\circ} \mathrm{C}$ for 5 min. Similar results were demonstrated with highly pathogenic avian influenza (HPAI) $\mathrm{H} 5 \mathrm{~N} 1$ virus, which was inactivated after exposure at $56^{\circ} \mathrm{C}$ for $30 \mathrm{~min}$ [3]. However, a significant amount of information is available on the resistance at high and low temperatures of AIVs but not all data are in agreement. Such as the $\mathrm{H} 5 \mathrm{~N} 1$ viruses were completely inactivated at $70^{\circ} \mathrm{C}$ for $60 \mathrm{~min}$ or at $75^{\circ} \mathrm{C}$ for 45 min [4]. Low pathogenic avian influenza (LPAI) H7N2 viruses were completely inactivated at $56^{\circ} \mathrm{C}$ after $60 \mathrm{~min}$ or at $60^{\circ} \mathrm{C}$ after $10 \mathrm{~min}$, while retained their infectivity in a water bath at $56^{\circ} \mathrm{C}$ after $30 \mathrm{~min}$ [5,6]. Additional study on AIV H7N3 indicated that the virus remained infectious after being treated at $56^{\circ} \mathrm{C}$ condition for $30 \mathrm{~min}$, but its infectivity was lost after for $60 \mathrm{~min}$ [7]. Our study suggested that the novel avian influenza A (H7N9) virus has not presented more tolerance to high temperature treatments.

AIV inactivation through UV light irradiation has a potential sterilizing application in the laboratories. The present study showed that UV light irradiation on the novel H7N9 virus is effective under the UV light exposure for $30 \mathrm{~min}$ or longer within $75 \mathrm{~cm}$ distance. However, the virus can survive if exposed to UV for shorter than $20 \mathrm{~min}$. The result suggested that enough UV exposure time is necessary for avoiding cross-contamination on

Table 3 Inactivation efficacy of pH conditions of the novel avian influenza $A$ (H7N9) virus

\begin{tabular}{|c|c|c|c|c|c|c|}
\hline \multirow{3}{*}{$\begin{array}{c}\mathrm{pH} \\
\text { values }\end{array}$} & \multicolumn{6}{|c|}{ Exposure time (hours) } \\
\hline & \multicolumn{2}{|c|}{0.5} & \multicolumn{2}{|c|}{1} & \multicolumn{2}{|c|}{24} \\
\hline & $\mathrm{AH} 1$ & $\mathrm{SH} 1$ & $\mathrm{AH} 1$ & $\mathrm{SH} 1$ & $\mathrm{AH} 1$ & $\mathrm{SH} 1$ \\
\hline 1 & $0 / 6^{*}$ & $0 / 6$ & $0 / 6$ & $0 / 6$ & $0 / 6$ & $0 / 6$ \\
\hline 2 & $0 / 6$ & $0 / 6$ & $0 / 6$ & $0 / 6$ & $0 / 6$ & $0 / 6$ \\
\hline 3 & $6 / 6$ & $6 / 6$ & $6 / 6$ & $6 / 6$ & $0 / 6$ & $0 / 6$ \\
\hline 4 & $6 / 6$ & $6 / 6$ & $6 / 6$ & $6 / 6$ & $6 / 6$ & $6 / 6$ \\
\hline 6 & $6 / 6$ & $6 / 6$ & $6 / 6$ & $6 / 6$ & $6 / 6$ & $6 / 6$ \\
\hline 8 & $6 / 6$ & $6 / 6$ & $6 / 6$ & $6 / 6$ & $6 / 6$ & $6 / 6$ \\
\hline 10 & $6 / 6$ & $6 / 6$ & $6 / 6$ & $6 / 6$ & $6 / 6$ & $6 / 6$ \\
\hline 11 & $6 / 6$ & $6 / 6$ & $6 / 6$ & $6 / 6$ & $6 / 6$ & $6 / 6$ \\
\hline 12 & $6 / 6$ & $6 / 6$ & $6 / 6$ & $6 / 6$ & $6 / 6$ & $6 / 6$ \\
\hline
\end{tabular}

Note: *Infectivity to embryonated chicken eggs = (infected embryos)/(total embryos inoculated; $\mathrm{n}=6$ ) per treatment. lab-works. In addition, other disinfection measures should be implemented after lab works since only microbes on the surface of material and in the air can be killed by UV light [8]. UV irradiation could be considered an appropriate method only when the surfaces are well cleaned and the source of light is positioned very close to the surfaces to be disinfected [9].

Orthomyxoviridae viruses are considered to be sensitive to acid $\mathrm{pH}$ values, although their retention of infectivity is dependent on degree of acidity and virus strain [10]. Our study indicated that the novel avian influenza H7N9 viruses may present a strong tolerance to both moderately acidic and higher alkali conditions. The H7N9 viruses lost their infectivity when exposed to less $\mathrm{pH} 2$ for 30 min or $\mathrm{pH} 3$ overnight conditions, while infectivity remained under $\mathrm{pH}$ 4-12 conditions for all contact times. However, previous studies suggested that different subtypes of influenza could present different tolerance to acidic or alkali conditions. LPAI H7N2 virus lost 100\% infectivity under pH 2 condition for $5 \mathrm{~min}$, but no effect exposure to $\mathrm{pH} 5$, 7, 10 or 12 for $15 \mathrm{~min}$ [6]. LPAI H7H3 was unable to maintain their infectivity after exposure to $\mathrm{pH} 1,3,10$ and 14 for $48 \mathrm{~h}$ [7]. The study on Thailand AIV H5N1 suggested that all ranges of $\mathrm{pH} 3,5,7,9$ and 12 could not inactivate the tested viruses after exposure for 5 and $10 \mathrm{~min}$ respectively [4].

In general, on the basis of their resistance to chemical agents, viruses can be divided into three categories (A, B and $\mathrm{C}$ ) according to the presence/absence of lipids on the virus particle and size of virus. AIVs belong to category A, which can be inactivated easily by all major classes of disinfectants if used properly [11]. Commercially available disinfectant products evaluated in this study, including Sodium Hypochlorite, Virkon ${ }^{\circledR}-S$ and ethanol, effectively disinfect the novel avian influenza H7N9 viruses at the recommended concentrations for 5 min at room temperature. Study demonstrated that the viral RNA of two LPAI strains H5N9 and H7N3 was completely damaged after exposure to Sodium Hypochlorite at recommended concentration [12]. AIV H5N1 was completely inactivated after treatment with acid hypochloride for $10 \mathrm{~min}$ [13]. The efficacy of Virkon ${ }^{\circledR}-\mathrm{S}$ against AIVs has been evaluated on H5N9 and H7N3, the results showed that the fresh Virkon ${ }^{\circledR}-\mathrm{S}$ solution at the recommended dilution was able to destroy the viral genome making it undetectable by real time RT-PCR [12]. $0.5 \%$ Virkon ${ }^{\circledR}-S$ was able to fully inactivate AIV after 90 min while $1 \%$ or $2 \%$ Virkon ${ }^{\circledR}-\mathrm{S}$ achieved virucidal activity after $30 \mathrm{~min}$ [7]. Ethanol is efficacious against AIVs and other enveloped viruses, our results demonstrated that the novel avian influenza H7N9 viruses were completely inactivated after $75 \%$ ethanol treatment for only $5 \mathrm{~min}$. As AIV H7N2, which lost its infectivity after treatment with $70 \%$ ethanol for 5 min or 
Table 4 The disinfection efficacy of disinfectants of the novel avian influenza A (H7N9) virus

\begin{tabular}{|c|c|c|c|c|c|c|c|}
\hline \multirow[t]{3}{*}{ Disinfectants } & \multirow[t]{3}{*}{ Component } & \multicolumn{6}{|c|}{ Exposure time (minutes) } \\
\hline & & \multicolumn{2}{|c|}{5} & \multicolumn{2}{|c|}{10} & \multicolumn{2}{|c|}{30} \\
\hline & & $\mathrm{AH} 1$ & $\mathrm{SH} 1$ & $\overline{\mathrm{AH} 1}$ & $\mathrm{SH} 1$ & $\mathrm{AH} 1$ & SH1 \\
\hline Ethanol & 75\% Ethanol & $0 / 6^{*}$ & $0 / 6$ & $0 / 6$ & $0 / 6$ & $0 / 6$ & $0 / 6$ \\
\hline \multirow[t]{2}{*}{ Chlorine compound } & $0.5 \%$ Sodium Hypochlorite & $0 / 6$ & $0 / 6$ & $0 / 6$ & $0 / 6$ & $0 / 6$ & $0 / 6$ \\
\hline & 1.0\% Sodium Hypochlorite & $0 / 6$ & $0 / 6$ & $0 / 6$ & $0 / 6$ & $0 / 6$ & $0 / 6$ \\
\hline \multirow[t]{2}{*}{ Virkon ${ }^{\circledR}-S$} & 0.5\% Dipotassium Peroxodisulphate & $0 / 6$ & $0 / 6$ & $0 / 6$ & $0 / 6$ & $0 / 6$ & $0 / 6$ \\
\hline & 1.0\% Dipotassium Peroxodisulphate & $0 / 6$ & $0 / 6$ & $0 / 6$ & $0 / 6$ & $0 / 6$ & $0 / 6$ \\
\hline
\end{tabular}

Note: *Infectivity on embryonated chicken eggs $=($ infected embryos)/(total embryos inoculated; $\mathrm{n}=6)$ per treatment.

15 min [5,6]. However, the disinfection efficacy also depends upon the strain of the virus, exposure time, quantity of the virus and nature of the medium used.

\section{Conclusion}

The results indicated that the novel avian influenza H7N9 viruses can be completely inactivated using high temperature (e.g. $56^{\circ} \mathrm{C}$ or above), UV light irradiation, and commercial disinfectants (Sodium Hypochlorite, Virkon ${ }^{\circledR}-\mathrm{S}$ and Ethanol). But the virus presents a high tolerance to moderately acidic or higher alkali conditions. The present results would provide essential information for public health intervention of novel avian influenza H7N9 outbreaks.

\section{Materials and methods}

The viruses and virus propagation

In March 2013, three urban residents of Shanghai or Anhui, China, were identified to be infected with AIVs A (H7N9) [1]. Understanding the potential effect of chemical and physical treatments on inactivation of the H7N9 virus is significant to the implementation of proper public intervention measures. Two avian influenza H7N9 viruses (A/Anhui/1/2013 and A/Shanghai/1/2013) were selected to assess its tolerance to varied physical conditions or chemical reagents in this study. The viruses were propagated in 9-day-old SPF embryonated chicken eggs in a $35^{\circ} \mathrm{C}$ humidified incubator, and the allantoic fluid(AF) was harvested after $48 \mathrm{~h}$ inoculation. The virus titres, determined as $\mathrm{EID}_{50} / \mathrm{ml}$, were evaluated according to the Reed and Muench method (Reed and Muench, 1938) [14]. The virus was divided into single-use tube, refrozen, and stored at $-80^{\circ} \mathrm{C}$ until further use.

\section{Treatment of AIVs A (H7N9) with physical conditions and chemical reagents \\ Temperature inactivation}

The avian influenza H7N9 viruses were subjected to the conditions of various temperatures. The efficacy of heat treatments inactivating H7N9 viruses was determined. The tested protocol was modified from Swayne and Beck [15]. For test of thermal inactivation, $50 \mu \mathrm{l}$ virus stock solutions containing $10^{7.7} \mathrm{EID}_{50}$ were added into thinwalled $0.2 \mathrm{ml}$ polypropylene thermocycler tubes (Axygen scientific, USA) and placed in a precision tube-holding heating block of the thermocycler with heated lid (Eppendorf Mastercycler, Germany) at different temperatures, including $56,65,70$ and $75^{\circ} \mathrm{C}$ for $5,10,15,30,45$ and $60 \mathrm{~min}$ and additionally, $70^{\circ} \mathrm{C}, 75^{\circ} \mathrm{C}$ and $100^{\circ} \mathrm{C}$ for 1 and $2 \mathrm{~min}$. The treated viruses were placed in an ice bath immediately to stop the heat treatment and $450 \mu \mathrm{l}$ PBS was added for inoculation of SPF embryonated chicken eggs.

\section{UV inactivation}

$50 \mu \mathrm{l}$ virus stock solution containing $10^{7.7} \mathrm{EID}_{50}$ was spread on Petri dish (Corning Incorporated, $35 \mathrm{~mm} \times 10 \mathrm{~mm}$ ) surface using $10 \mu \mathrm{l}$ tip (Axygen scientific, USA) and exposed to UV light (distance of $75 \mathrm{~cm}$ and wavelength of 250-270 nm) in Biosafety Cabinet (Sterilgard ${ }^{\circledR}$ III advance, the Baker Company) at room temperature. The cover of the Petri dish was removed when samples were exposed to the UV light, $450 \mu \mathrm{l}$ PBS was added to the Petri dish after UV exposure for 10, 20, 30, 45 and 60 min respectively. And then the recovery of the virus was tested immediately by inoculation of SPF embryonated chicken eggs.

\section{The tolerance of AIVs A (H7N9) on varied $\mathrm{pH}$ conditions}

To determine the tolerance of the novel virus on the acidic and alkali conditions, the viruses $\mathrm{AH} 1$ and $\mathrm{SH} 1$ were exposed to different $\mathrm{pH}$ values (1-12) for different time intervals at room temperature, as described in previous study with some modifications [16]. $50 \mu \mathrm{l}$ virus stock solutions containing $10^{7.7} \mathrm{EID}_{50}$ were mixed thoroughly with $450 \mu \mathrm{l}$ PBS with pH 1, 2, 3, 4, 6, 8, 10, 11 and 12, adjusted by using sodium hydroxide or hydrochloric acid, and treated for $0.5,1$ and $24 \mathrm{~h}$ at room temperature respectively. And then the recovery of the virus was tested immediately by inoculation of SPF embryonated chicken eggs.

\section{Disinfectants inactivation}

Commercial disinfectants, including Sodium Hypochlorite, Virkon ${ }^{\circledR}-\mathrm{S}$ (Antec ${ }^{\mathrm{Th}}$ International, UK) and ethanol, were 
tested in this study. The tested protocol was modified from Suarez et al. [12]. Briefly, all disinfectants were diluted with distilled water following the manufacturers' recommendation. $50 \mu \mathrm{l}$ virus stock solutions containing $10^{7.7}$ EID $_{50}$ were mixed thoroughly with $450 \mu \mathrm{l}$ of each working disinfectant, $4.5 \mathrm{ml}$ PBS was added to the mixture to stop the disinfection after 5,10 , and $30 \mathrm{~min}$ treatment at room temperature respectively. And then the recovery of the virus was tested immediately by inoculation of SPF embryonated chicken eggs.

\section{Virus inactivation testing in SPF embryonated chicken eggs}

All treated viruses were inoculated into 9-day-old SPF embryonated chicken eggs to determine their survival. Each of the virus suspension exposed to physical conditions (temperature, ultraviolet light and $\mathrm{pH}$ ) was made 10fold dilution with PBS, 100-fold dilution for the untreated virus stock solution as positive control, 10-fold dilution for each disinfectant control. Each diluted samples was filtered through $0.22 \mu \mathrm{m}$ filter (Milliplex ${ }^{\mathrm{Tm}}$, Millipore corp., Bedford, MA, USA) before inoculation into six 9-day-old SPF embryonated chicken eggs for 72-96 h. Embryo mortality observed within $24 \mathrm{~h}$ post inoculation was considered nonspecific and discarded. Allantoic fluid (AF) was collected from each egg and checked for HA as the sign of viral growth in the eggs.

\section{Biosafety levels}

In view of the biosafety issues involved in handling avian influenza H7N9 viruses, all the experiments were conducted in a biosafety level 3 facility for this study.

\section{Abbreviations \\ AIV A (H7N9): A novel reassortant avian-origin influenza H7N9 virus; AIV: Avian influenza virus; UV: Ultraviolet light; EID 50 : 50\% egg infectious dose; AH1: A/Anhui/1/2013(H7N9); SH1: A/Shanghai/1/2013(H7N9); HA: Haemagglutination assay; HPAl: Highly pathogenic avian influenza; LPAI: Low pathogenic avian influenza; SPF: Specific pathogen-free; AF: Allantoic fluid.}

\section{Competing interests}

The authors declare no competing interests. The contents of this article are solely the responsibility of the authors and do not necessarily represent the views of China CDC and other organizations.

\section{Authors' contributions}

YLS designed the research and draft the paper; SMZ and JFG performed the research; SMZ and RBG joined into the designation of the study, analysed the data and draft the paper; LBD,YZ, JD and HB helped with titration of the virus; JFZ and KQ helped to draft the manuscript. All authors read and approved the final manuscript.

\section{Acknowledgements}

This study was supported by Emergency Research Project on human infection with avian influenza H7N9 virus from the National Ministry of Science and Technology (No. KJYJ-2013-01-01 to Dr. Shu) and the National Basic Research Program (973) of China (grant No. 2011 CB504704 to Dr. Shu).

\section{Author details}

${ }^{1}$ Chinese National Influenza Center, National Institute for Viral Disease Control and Prevention, 155 Changbai Road, Beijing 102206, P.R China. ${ }^{2}$ Key
Laboratory for Medical Virology, National Health and Family Planning Commission, 155 Changbai Road, Beijing 102206, P.R China. ${ }^{3}$ National Institute for Viral Disease Control and Prevention, China CDC, Key Laboratory for Medical Virology, National Health and Family Planning Commission, 155 Changbai Road, Beijing 102206, P.R China.

Received: 24 June 2013 Accepted: 2 September 2013

Published: 15 September 2013

\section{References}

1. Gao R, Cao B, Hu Y, et al: Human infection with a novel avian-origin influenza A (H7N9) virus. N Engl J Med 2013, 368(20):1888-1897.

2. Avian influenza $A(H 7 N 9)$ virus. (n.d.). World Health Organization. Report 9 data in WHO/HQ as of 12 August 2013. http://www.who.int/influenza/ human_animal_interface/influenza_h7n9/09_Report Web H7N9 Number pdf.

3. Shahid MA, Abubakar M, Hameed S, Hassan S: Avian influenza virus (H5N1); effects of physico-chemical factors on its survival. Virol J 2009, 6:38.

4. Wanaratana S, Tantilertcharoen R, Sasipreeyajan J, Pakpinyo S: The inactivation of avian influenza virus subtype $\mathrm{H} 5 \mathrm{~N} 1$ isolated from chickens in Thailand by chemical andphysical treatments. Vet Microbiol 2010, 140:43-48.

5. Castro AE, Lu H, Senne D, Henzler D: Biologic and molecular characteristics of the H7N2 subtype of avian influenza virus isolated during a 1997 field outbreak in layerflocks. In Proceeding of the 47th Western Poultry Disease Conference. Sacrament, CA; 1998:69-70.

6. Lu H, Castro AE, Pennick K, Liu J, Yang Q, Dunn P, Weinstock D, Henzler D: Survival of avian influenza virus H7N2 in SPF chickens and their environments. Avian Dis 2003, 47(Suppl. 3):1015-1021.

7. Muhammad KP, Das T, Yaqoob A, Riaz, Manzoor R: Effect of physicochemical factors on survival of avian influenza virus (H7N3 type). Int $J$ Agric Biol 2001, 4:416-418.

8. Nicklin J, Graeme-Cook K, Paget T, Killington RA: Instant notes in microbiology. BIOS Sciencetific Publishers; 1999:102

9. Samberg Y, Meroz M: Application of disinfectants in poultry hatcheries. Rev Sci Tech 1995, 14:365-380.

10. Puri A, Booy FP, Doms RW, White JM, Blumenthal R: Conformational changes and fusion activity of influenza virus haemagglutinin of the $\mathrm{H} 2$ and H3 subtypes: effects of acid pretreatment. J Virol 1990, 8:3824-3832.

11. Prince $H N$, Prince DL: Principles of viral control and transmission. In Disinfection, sterilization, and preservation. Edited by Block SS. Philadelphia: Lippincott Williams \& Wilkins; 2001:542-574.

12. Suarez DL, Spackman E, Senne DA, Bulaga L, Welsch AC, Froberg K: The effect of various disinfectants on the detection of avian influenza virus by real time RT-PCR. Avian Dis 2003, 47:1091-1095.

13. Songserm T, Jam-on R, Sae-Heng N, Meemak N: Survival and stability of HPAI H5N1 in different environments and susceptibility to disinfectants. In Developments in Biologicals, Volume 124. Edited by Schudel A, Lombard M. Karger, Switzerland: Developments in Biologicals; 2006:254.

14. Reed $\sqcup$, Muench $\mathrm{H}$ : A simple method of estimating fifty percent end points. Am J Hyg 1938, 27:493-497.

15. Swayne DE, Beck JR: Heat inactivation of avian influenza and Newcastle disease viruses in egg products. Avian Pathol 2004, 33:512-518.

16. Stallknecht DE, Kearney MT, Shane SM, Zwank PJ: Effect of pH, temperature, and salinity on persistence of avian influenza viruses in water. Avian Dis 1990, 34:412-418.

doi:10.1186/1743-422X-10-289

Cite this article as: Zou et al:: Inactivation of the novel avian influenza A (H7N9) virus under physical conditions or chemical agents treatment. Virology Journal 2013 10:289. 